\title{
CHOMOTHERAP' OF LEPROS'.
}

Chimical, explikimintal. ani) Cilnical. Stuidi:s (*) (***)

(Translated from Rew. Brasileira de Leprologia, 1949, Vol. XVII, N'o. j.)

Since the second half of 1943 works have been appearing in scientific literature concerning the favourable results of the clinical use of sulphones in the treatment of leprosy. In October I 944 the use was commenced in patients of the Sanatorio Paclro Bento (I)E SOUZA LIMA, L, IIa, Conferencia Panamericana de Lepra Vol. II, page 9-I946; see also International Journal of Leprosy, I6, 127-I37-I948) of symmetrical bi-substituted derivatives of 4:4'-diaminodiphenylsulphone (a) formaldehyde sulphoxylate (b) glucose-sulphonate and encouraging results having been observed, the need was seen for a closer study of diverse chemotherapentic 
aspects of leprosy. By combining chemical, experimental ancl clinical studies it was thought that we should contribute to the solution of the problems of the prophylaxis and treatment of leprosy, aclvantage being taken of the splendicl human material available and having recourse to the limited technical personnel available.

The synthesis of chemotherapeutic substances; experimental and clinical studies, and finally production on a larger scale to enable the application of the substances to be tried at all hospitals and dispensaries in Brazil-these are the general lines of our purpose.

This note, the first of a series, aims to put forward the general plan of work summarising the results and the conclusions so far obtaineel. It is in three parts:

\section{CHEMICAL.}

Details are given of the work done to prepare compounds already known to be active chemotherapeutic agents in leprosy, and of the general lines followed in the synthesis of compounds intended for further trial.

\section{EXPERIMENTAL.}

After giving a summary of the working methods devised, the first results obtained with the products submitted to tests in laboratory animals are detailed.

\section{CIINICAL.}

A summary is given of the observations made during the application of the compounds studied in man.

\section{(IIIEMICAL, STUIDIES.}

\section{H. Rheinhoidt, F. A. Berti, C. Pereg(), B. H. G. Rifckmann,} H. W. RZEPPA.

Since May of 1946 we have been working on the following programme:

( I) Devising a method of synthesis for large scale preparation of 4:4'-diaminodiphenylsulphone (d.d.s.) and derivatives thereof with a view to filling the needs of the Leprosaria of S. Paulo State and later of Irazil, with sufficient quantities of antileprotic medicaments.

(*) Contrilution by The Scientific Research Service of the lepartment of Ieprosy Prophylaxis of the State of $\mathrm{S}$. Paulo and l,y the "Fundaçao Paulista contra a Itepra."*

(*) Chcimical Studies hy H. Rheinholelt, F. A. Terti, C. Perego, B, H, G. Rieckmann R. 11.11 Rzepra in the Chemotheranentic P'roflucts Laboratory of the Butantan Institute; Expcrimcutal Studics: A.C. Mauri \& W. A. Ilarller at the Concle I-ara Institute, S. l'aulo: Clinical Studics: I. de Somza I.ima at the l'adre bento Hospital, S. T'aulo.

Receiverl for pullication on the 28 th Tulv, 19 is. 
To prepare on a large scale the formaldehycle-sulphoxylic derivative of $4: 4^{\prime}$-cl.d.s. because this is the compound most recommended by clinicians at our leprosaria.

(2) To prepare other sulphone derivatives already recognised as of use in human leprosy, in order to make possible their application in Brazil thus overcoming the difficulties of importation and home production.

(3) While profiting by the chemical, experimental and clinical experience acquired cluring the studies of chemical synthesis with tests on laboratory animals and with the therapeutic application of the known derivatives, to investigate at the same time:-

(a) possible improvements on compounds of known therapeutic activity (4:4'-diaminodiphenylsulphone-bis-Nmethylene-sulphoxylate of sodium).

(b) to synthesise sulphone or other compounds, the activity of which as anti-leprotics has not yet been tested.

The parts of this programme that have been realised are as follows:-

With regard to our present manufacture of $4: 4^{\prime}$ d.d.s. based upon the method devised by us, Table No. I schematises the various phases and reactions and also indicates the average yield and the total quantity in kilogrammes of the various products manufactured in 15 months of activity.

TABIE No. I.

\begin{tabular}{|c|c|c|}
\hline $\begin{array}{l}\text { Wanufacturing Process of } \\
\text { f:4'-diaminorliphenylsulphone }\end{array}$ & $\begin{array}{l}\text { Average } \\
\text { Yielels }\end{array}$ & $\begin{array}{l}\text { Total } \\
\text { Manufactured }\end{array}$ \\
\hline \multicolumn{3}{|l|}{ CHICIR()BENZINE } \\
\hline$\downarrow$ Chlorosulphonic Aciol & & \\
\hline 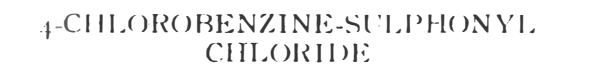 & $86 \%$ & $5.19 \mathrm{Kg}$. \\
\hline$\downarrow \begin{array}{l}\text { Aluminium Chloride } \\
\downarrow\end{array}$ & 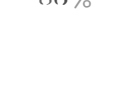 & $3+9$ र \\
\hline $\begin{array}{l}4: \downarrow^{\prime} \text {-Dichlorodiphenylsulphone } \\
\downarrow \\
\downarrow\end{array}$ & $71 \%$ & $497 \mathrm{Kg}$. \\
\hline 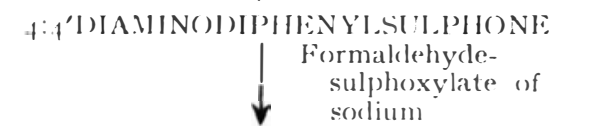 & $72 \%$ & $221 \mathrm{Kg}$. \\
\hline 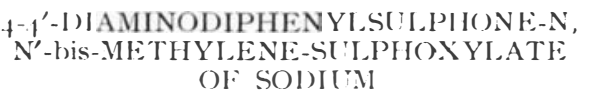 & $89 \%$ & $306 \mathrm{Kg}$. \\
\hline
\end{tabular}


TABLE No. II

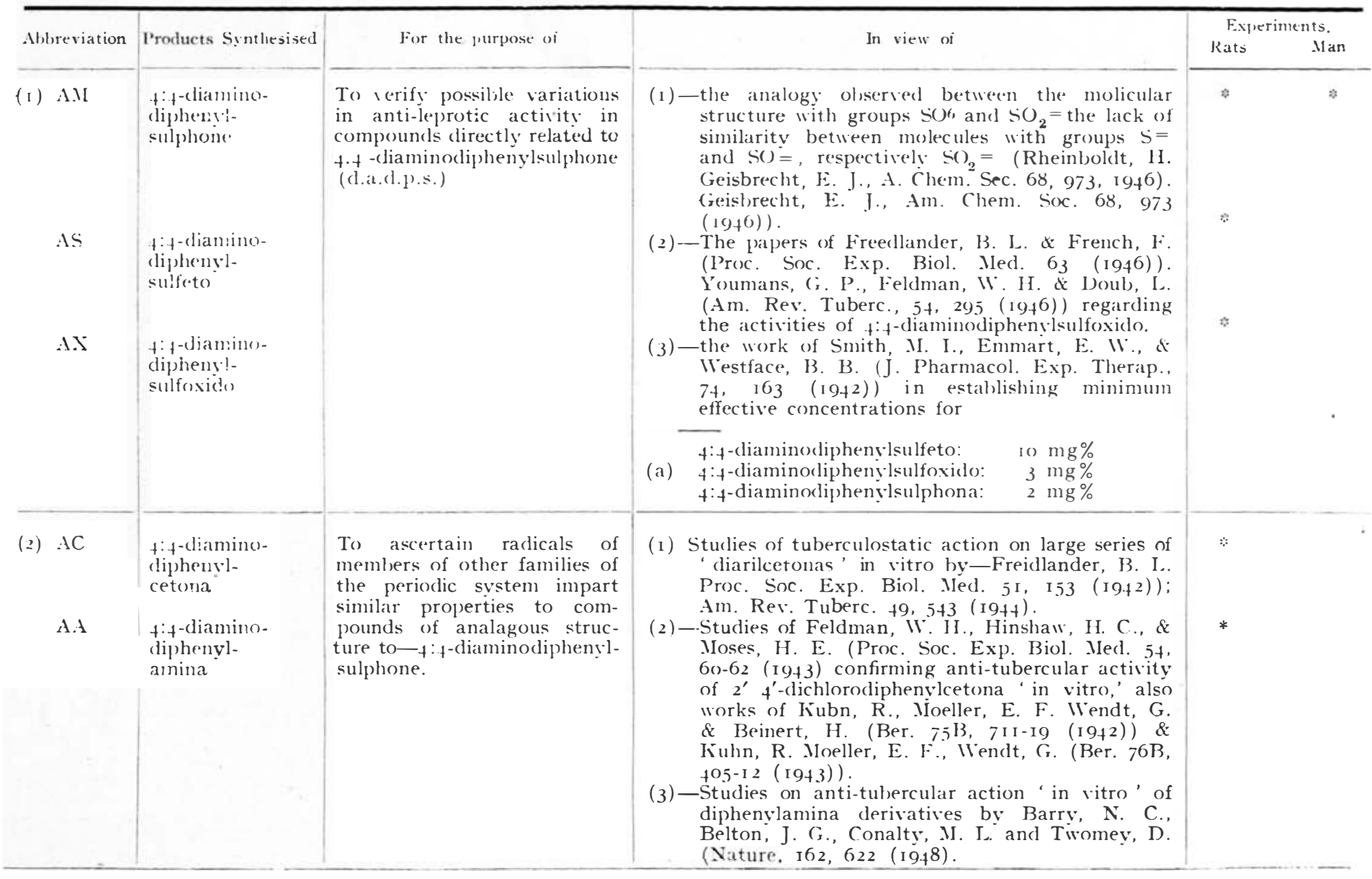


(4) A.MT 4:4-Ditrichloroacetila mino-dipheny-lsulphona

(5) AMBS $_{1}$ 4:4-1)iaminodiphenylsulphona-n, $-n^{\prime}$ bis-metilenosulfonato de sodio

(6) Ancit tif-diaminodiphenyl-sulfonan,n'-bis-glucose

To verify if the introduction of 2 trichloracetyl radicals in the molecule of $+t+$ cl.a.d.p.s. would increase the activitity of this compound against the bacillus of Hansen or Stefansky.

To apply clinically a compound in structure similar to the corresponding sulfoxylic derivative; but, in contrast, derivative; but, in contrast,
stable, easily purified to the degree necessary for intravenous administration as opposed to all previous compounds.

To examine the administration of a hypersoluble derivative of $4: 4$ d.a.d.p.s. in the form of a combination which would liberate the active substance quickly in contact with the tissues.

(7) A.ICH Diphenylsulfona $\left(4: 4^{\prime}\right)$-bis- $(7-a z 0-$ 8-hydroxylTo introduce a molecule of fif d.a.d.p.s. into a compound similar to trypan blue. amino-nattaleno$(3,6)$ ) -disulfonato sodico

(8) APiS Acido p-Aminosalicilico

To verify chemotherapeutic activity in murine and
(1) Known properties of formol in inhibiting growth of microrganisms.

(2)-Conclusions of Jouin, I. P \& Buu-Boi (Ann. Inst. Pasteur, 72, 580-606 (1946)) attributing to the aldehyde group the inhibition of growth of M.tuberculosis ' in vitro.'

Studies by: Bergmann, F., et de (J. Am. Chem. Soc., 63, I+37 (I9+I)); (J. Chem. Soc. I, I939; 576 I 940$)$.

The difficulty in administering the methyl sulphoxyl derivative of $4: 4$ d.a.d.p.s. by the intravenous route because of its instability in acqueous solution and the difficulty in sterilising completely.

(1) -The known activity of 4 :f-cl.a.d.p.s by oral administration.

(2)-Experiments by: Jensen, K. A., Freclerikson, E. \& Kioer, I. (Acta. Path. Microbiol. Scand. suppl. 5t, 277-30t (194t) C.A. fo, 3195 (1946) on action of galactoside derivatives in tuber. culosis in guinea pig.

The known afinity of trrpan blue for the reticuloendotheline system. human leprosi.
Observations to date of its ' in vivo' and 'in vitro' application in Tuberculosis.

-

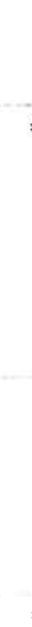


In this table is inclucled also a fourth phase which leads to the formalchehyde-sulphoxylate derivative of $4: 4^{\prime}$ d.d.s., a product which was supplied to the leprosaria for clinical operation in a total quantity of 947,800 sugar-coated tablets of 0.33 -gme. each. For further cletails upon the elaboration of the method on which this process of manufacture is based, see Berti, F. A., Rieckmann, B. H. G., Perego, G. and Rzeppa, H. W. Mem. Inst. Butantan, 21, IO7-116-1949.

With a view to industrial production synthetic processes were studied for 4:4'-d.d.s. derivatives (a) N, N'-bis-gamme-phenylpropyl-disulphone and (b) N, $\mathrm{N}^{\prime}$-bis-dextrose-sulphone, as also of 2-amino-5-sulphänilylthic\%ol.

\section{(Summarised)}

In studies on the sensitivity and exactitude of colorimetric methods of determination of 4:4-d.d.s. and derivatives thereof in body fluids, it was accidentally observed that, as used in clinical practice, the formaldehycle-sulphoxylate derivative of $4 \cdot 4^{\prime}$-d.d.s. is accompanied always by considerable quantities of impurities. ()ur work proceeded therefore along various lines:

(a) To obtain this derivative in the purest possible state in order to exclude any possible influence of impurities.

(b) To cletermine the chemical nature of the impurities in order to verify whether these and not the sulphone group of the molecule are responsible for any part of the action of these derivatives in leprosy.

(c) To clevise a quantitative method of determination for the formaldehyde-sulphoxylate derivatives of $4: 4$ d.d.s. to provide precise analytical data as a basis for our conclusions and to control the inclustrial manufacture of the product.

With regard to the synthesis of sulphone or other compounds with a view to testing the anti-leprotic activity thereof, various substances were prepared and submitted to chemotherapeutic tests against Stefansky's bacillus in rats and against Hansen's bacillus in man. In the choice of compounds for synthesis we took as a basis chiefly results already obtained or principles already applied in the chemotherapy of acid-alcohol resistant bacilli and especially M.tuberculosis. We were led to this by the absence or uncertainty of any bacteriological or chemotherapeutic experience with murine leprosy and the scarcity of decisive results in human leprosy.

Table No. 2 gives those of the various compounds sythesised by us which have already been subjected to animal or clinical experimentation, summarising the reasons why they were selected. 
Table No. 3 gives the methods of preparation (*) of compounds forming part of a series of substances structurally related to 4:4-d.d.s., the purpose being to find chemotherapentic substances of greater activity than the latter.

${ }^{*}$ ) The technical part of such preparation was carried out by lizwaldo, .1. . . . (see original), 1.1 .39 .

TABLLE No. 3.

\begin{tabular}{|c|c|c|}
\hline Abłreviation & Methocls of l'reparation. & References. \\
\hline AS & $\begin{array}{l}\text { Reduction of f-nitro-f'-amino- } \\
\text { cliphenylsulphicle with metallic } \\
\text { tin in hyclochloric aciol. }\end{array}$ & 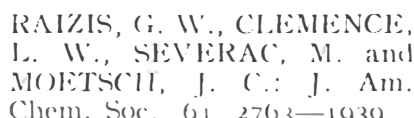 \\
\hline$\Lambda X$ & $\begin{array}{l}\text { ()xidation of }+\cdot f^{\prime} \text {-cliamino- } \\
\text { (liphenylsulphicle lith per- } \\
\text { hydrol in acctone. }\end{array}$ & 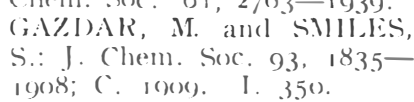 \\
\hline$A .1$ & See Table No. I. & \\
\hline $\mathrm{AC}$ & $\begin{array}{l}\text { (a) Oxiclation of } 4 \cdot f^{\prime} \text {-dichloro- } \\
\text { diphenyldichlorethylene to } \\
4 \cdot f^{\prime} \text {-clichloro-diphenyl-ketone } \\
\text { with chromic anhydride. }\end{array}$ & $\begin{array}{l}\text { (a) (iRUMMITL, (), BICK, } \\
\text { A. and JENkINS, A.; J. } \\
\text { Am. Chem. Soc., } 67,15.5 \\
-19+5 .\end{array}$ \\
\hline 11 & $\begin{array}{l}\text { (b) Amination under pressure } \\
\text { of f..t' dichlorodiphenylketone. } \\
\text { Reduction of } 4 \cdot f^{\prime} \text {-clinitro- } \\
\text { diphenylamine with metallic } \\
\text { tin in hylrochloric acid. }\end{array}$ & 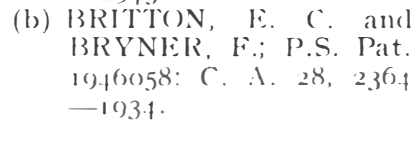 \\
\hline$\triangle P A S$ & $\begin{array}{l}\text { Morlified kolbe reaction } \\
\text { applies to m-aminophenol. }\end{array}$ & 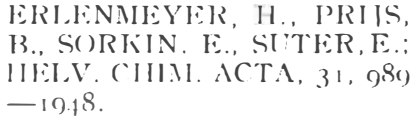 \\
\hline
\end{tabular}

Table No. 4 schematises the courses followed in the preparation of symmetrical bi-substituted derivatives of $4: 4^{\prime}$-d.d.s. with a view to reinforcing its chemotherapeutic activity.

TABLE N(). 4.

\begin{tabular}{|c|c|c|c|c|}
\hline \multicolumn{5}{|c|}{ 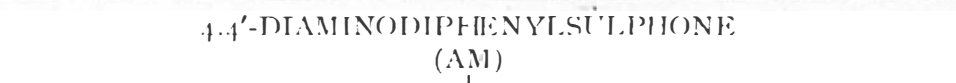 } \\
\hline $\begin{array}{l}\text { formic } \\
\text { acid }\end{array}$ & $\begin{array}{c}\text { trichloraceticaciol } \\
\text { and phosphorus } \\
\text { oxychloricle }\end{array}$ & $\begin{array}{c}\text { formaldehyde- } \\
\text { sodium } \\
\text { bisulphite }\end{array}$ & $\left.\right|_{1} ^{\text {glucose }}$ & $\begin{array}{l}\text { diazotisation } \\
\text { and coupling } \\
\text { with H acid }\end{array}$ \\
\hline A.MF & AMT & $\mathrm{AMPS}_{1}$ & A.MIC & AMCH(*) \\
\hline
\end{tabular}

(*) A preparation of this compound was effected hy. Sr. Túlin T'ulles.

The results of these two latter aspects of our synthetic work will be published in detail in other notes in this series.

The following parts of the present note relate to conclusions upon the activity of these compounds in murine leprosy and human leprosy. 